SUSTAINABLE FORESTRY

COLLECTION 83-84, 2021
ODRŽIVO ŠUMARSTVO

ZBORNIK RADOVA 83-84, 2021

DOI: $10.5937 /$ SustFor2183013C

Original scientific paper

\title{
THE REMOVAL OF PATHOGENIC MICROORGANISMS IN A BIOLOGICAL SYSTEM WITH FLOATING ISLANDS
}

\author{
Nevena $\check{C} U L E^{1}$, Aleksandar LUČIĆ ${ }^{1}$, Marija NEŠIĆ ${ }^{2}$, Ljiljana BRA $\check{S} A N A C$ - \\ BOSANAC ${ }^{l}$, Suzana MITROVIĆl, Milorad VESELINOVIĆl, \\ Tatjana ĆIRKOVIĆ-MITROVIĆ ${ }^{1}$
}

\begin{abstract}
Pathogenic microorganisms in water pose a great risk to human health. Therefore, it is necessary to find an efficient, environmentally friendly, and economically acceptable solution for their removal from polluted and wastewater. This paper presents the efficiency of a biological system with floating islands in the removal of pathogenic microorganisms from the water of a polluted urban river. The modified floating treatment wetland consisted of a collection tank, 4 calls with floating islands and 1 cell with algae, which enabled additional water polishing. The results of the research showed that the biological system constructed on the bank of this river had a high efficiency in reducing the number of various groups of pathogenic microorganisms. Within the cells with the floating islands, $100 \%$ efficiency in the removal of coliform bacteria of faecal origin was achieved, and the reduction of pathogens was continued within the cell with algae. The realised efficiency of removal of total coliform bacteria was $100 \%$ in all cells, except in the cell 4 with decorative aquatic macrophytes, in which the efficiency was 97\%. The number of intestinal enterococci was reduced in the range of 92 to $97 \%$ in cells with plants, and up to 98\% in the cells with algae. The floating islands and algae also enabled a high reduction in the number of aerobic heterotrophs and facultative oligotrophs. In addition, the ratio of these microorganisms had a value above 1 during the entire period of water treatment, which indicated that natural processes of self-purification of polluted water ran smoothly in

\footnotetext{
${ }^{1}$ Nevena Čule, PhD, Aleksandar Lučić, PhD, Ljiljana Brašanac-Bosanac, PhD, Suzana Mitrović, $\mathrm{PhD}$, Milorad Veselinović, PhD, Tatjana Ćirković-Mitrović, PhD, Institute of Forestry, Kneza Višeslava 3, 11030 Belgrade, Serbia

${ }^{2}$ Marija Nešić, PhD, Faculty of Forestry, University of Belgrade, Kneza Višeslava 1, 11030

Belgrade, Serbia

Corresponding author: Nevena Čule, PhD, e-mail: nevena.cule@yahoo.com
} 
the floating treatment wetland. Due to the reduction of pathogenic microorganisms, water that belonged to class V, i.e., III, after the discharge from the biological system, had the characteristics of water with excellent ecological status (class I).

Key words: rhizofiltration, plants, algae, polluted water, urban river.

\section{UKLANJANJE PATOGENIH MIKROORGANIZAMA U BIOLOŠKOM SISTEMU SA PLUTAJUĆIM OSTRVIMA}

Izvod: Patogeni mikroorganizmi u vodama predstavljaju veliki rizik po ljudsko zdravlje. Zbog toga je neophodno naći efikasno, ekološki pogodno i ekonomski prihvatljivo rešenje za njihovo uklanjanje iz zagađenih i otpadnih voda. Ovaj rad prikazuje efikasnost biološkog sistema sa plutajućim ostrvima u uklanjanju patogenih mikroorganizama iz vode zagađene urbane reke. Modifikovani biološki sistem se sastojao od sabirnog rezervoara, 4 bazena sa plutajućim ostrvima i 1 bazena sa algama, koje su omogućile dodatno poliranje vode. Rezultati istraživanja su pokazali da je biološki sistem konstruisan na obali ove reke imao visoku efikasnost u redukciji brojnosti različitih grupa patogenih mikroorganizama. $U$ okviru bazena sa plutajućim ostrvima ostvarena je 100\% efikasnost u uklanjanju koliformnih bakterija fekalnog porekla, a u okviru bazena za algama redukcija patogena je nastavljena. U svim bazenima ostvarena je efikasnost uklanjanja ukupnih koliformnih bakterija od 100\%, osim u četvrtom bazenu sa dekorativnim akvatičnim makrofitama u kome je efikasnost bila 97\%. Broj crevnih enterokoka je redukovan u granicama 92-97\% u bazenima sa biljkama, a u bazenu sa algama do 98\%. Plutajuća ostrva $i$ alge su omogućili $i$ visoko smanjenje brojnosti aerobnih heterotrofa i fakultativnih oligotrofa. Pored toga, odnos ovih mikroorganizama je imao vrednost iznad 1 tokom celog perioda prečišćavanja, što je ukazalo da su se u sistemu neometano odvijali prirodni procesi samoprečišćavanja zagađene vode. Zahvaljujući redukciji patogenih mikroorganizama voda koja je pripadala V odnosno III klasi je po izlasku iz biološkog sistema imala karakteristike vode sa odličnim ekološkim statusom (I klasa).

Ključne reči: rizofiltracija, biljke, alge, zagađena voda, urbana reka.

\section{INTRODUCTION}

The most common risk to human health associated with water comes from the presence of microorganisms that cause various diseases (Jasper et al., 2013). Surface waters contain a variety of microorganisms, including bacteria, fungi, protozoa, and algae, some of which can produce toxins, transmit, or cause diseases. Moreover, various intestinal pathogens can be found in water, such as Salmonella sp., Shigella sp., Escherichia coli and others. (Chapman and Kimstach, 1996). Sewage, agricultural runoff, and rainwater as well as household wastewater which are often mixed with each other and discharged into rivers without prior treatment pose a big problem. Such waters carry with them various pathogens and pose a great risk. A typical municipal sewage can contain from 10 to 100 million coliform bacteria in $100 \mathrm{ml}$ and 1 to 50 million Escherichia coli or faecal streptococci in 100 $\mathrm{ml}$ (Chapman and Kimstach, 1996). A serious problem arises also when it is impossible to completely remove pathogenic microorganisms by conventional water treatment, which leads to their potential appearance in drinking water. 
Various biological systems, such as constructed wetlands or floating islands, have the ability to remove various pollutants from polluted waters. (Čule et al., 2021; Čule et al., 2017; Kadlec and Wallace, 2008; Sharma et al., 2021; Vymazal, 2007). The removal occurs by imitation of natural processes, without the use of chemicals and additional energy, and due to the symbiotic relationship between the basic components of biological systems such as plants, algae, small invertebrates, zooplankton, microorganisms, substrate, and water. (BrašanacBosanac et al., 2020; Chen et al., 2017; Davis, 1995; Prasad and de Oliveira Freitas, 2003; Yeh et al., 2015). In recent years, great interest has been shown in the use of these nature-based solutions for the removal of pathogenic microorganisms from water (Vymazal, 2011). Although there are different opinions about their effectiveness in reducing pathogens (Ghermandi et al., 2007; Watson et al., 1989) it is evident that they can be used independently, within hybrid systems or as a complement to conventional treatment (Jasper et al., 2013). Floating islands, which are used for the treatment of polluted waters, consist of mash platforms, substrate, and terrestrial and aquatic plants with associated beneficial microorganisms (Benvenuti et al., 2018; Chance et al., 2019; Sharma et al., 2021). They can be placed within existing reservoirs, basins or directly on a river or a lake.

Topčiderka river has been used for years as a collector of wastewater, rainwater, agricultural and urban runoff, and industrial wastewater. Therefore, throughout the year its water is within the limits of class $\mathrm{V}$ based on most chemical, physical chemical and microbiological parameters for water quality assessment. (Čule et al., 2017). The sources of pollution of this urban river are numerous, and its high pollution also endangers the integrity of the water of the Čukarički Rukavac armlet located near the most important recreational centre in Belgrade. To examine the possibility of using biological systems for the treatment of a polluted river, a modified floating treatment wetland (FTW) was constructed on its bank. This paper presents the achieved efficiency of an environmentally friendly and cost-effective solution for the removal of pathogenic microorganisms from water.

\section{MATERIAL AND METHODS}

The biological system consisted of a collection tank $\left(5.0 \mathrm{~m}^{3}\right)$ and four cells with floating islands (area $3.0 \mathrm{~m}^{2}$ and volume $3.0 \mathrm{~m}^{3}$, each) (Figure 1). To provide additional polishing of water the fifth cell with algae was added (area $3.0 \mathrm{~m}^{2}$ and volume $1.5 \mathrm{~m}^{3}$ ). The collection tank and cells were placed on levelled soil and connected with plastic pipes (Čule et al., 2017). A water meter was placed on each supply branch of cells 1-4, which enabled precise control of the amount of water coming from cells with floating islands to cell 5. In this way, equal amounts of water from cells 1-4 were poured into the cell with algae. Owing to the inlet and outlet construction of the collection tank and cells, the water moved gravitationally through the system (Čule et al., 2017). Since the coverage of the cells with floating islands was $100 \%$, anaerobic conditions were expected in them. To introduce a larger amount of dissolved oxygen into the FTW, the inlet into the cell 5 was placed on its upper edge, i.e., $50 \mathrm{~cm}$ above the ground (Figure 2). In this way, but 
also due to larger free water surface, an additional reduction of pollutants is enabled, for the removal of which an aerobic environment is necessary. In each of the four cells there were 3 floating islands $(1.0 \mathrm{~m} \mathrm{x} 1.0 \mathrm{~m})$. The buoyant platform of the floating islands was made of light thermoplastic mass, with handrails and circular openings at the bottom (diameters $8.4 \mathrm{~cm}$ and $5.0 \mathrm{~cm}$ ). Stone wool was used as a substrate. The platform construction has enabled floating of the islands on the water and maintaining of above-ground biomass above its surface, as well as the growth of roots and rhizomes in the water. Non-invasive plants and plants suitable for rhizofiltration (Blaylock and Huang, 2000; Čule et al., 2021; Čule et al., 2016; Dushenkov et al., 1995; Kumar et al., 1995; Salt et al., 1995) were used to form the vegetation of floating islands. Total of 25 (cells 1-3) or 30 (cell 4) seedlings were planted on each island. Phragmites australis (Cav.) Trin. ex Steud, was planted within cell 1, Canna indica L. in cell 2 , while in cell 3 there was a mix of $P$. australis and $C$. indica at the ratio of 12:13. On each island in cell 4 there were also mixed plantations created by planting Iris pseudacorus L. (8 seedlings), Iris sibirica 'Perry's Blue' (5 seedlings), Alisma plantago - aquatica L. (5 seedlings), Lythrum salicaria L. (5 seedlings) and Menyanthes trifoliata L. (6 seedlings) (Figure 1). Algae were introduced in into cell 5 directly from the river. A monoculture of macroscopic algae from the genus Cladophora sp. was formed within this cell (Figure 2).
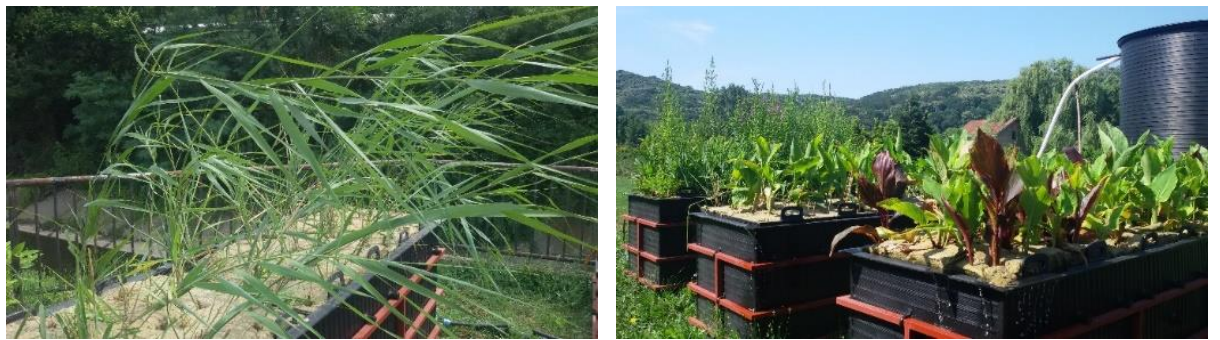

Figure 1. Cells with floating islands (cell 1 - on the left; cells 2-4-on the right)

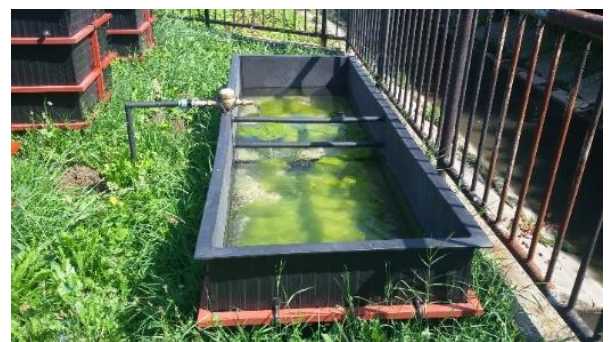

Figure 2. Cell 5 with algae and construction of water inlet

The FTW start-up period lasted a month and a half, after which the monitoring of its efficiency in the removal of pollutants began. The treatment cycle began by bringing water from the river into the collection tank by means of a pump and further distribution of water, by gravitational flow, simultaneously to cells 1-4. Hydraulic retention time (HRT) in cells was 6 days. After this period the water 
flowed due to gravity into cell 5, where it also remained for 6 days. The water treatment was then completed, and the treated water was discharged into the river.

To examine the quality of polluted and purified water on the basis of sanitary and microbiological parameters, water sampling was performed according to the standard method SRPS EN ISO 19458: 2009 (Water quality - Sampling for microbiological analyses). Polluted water samples were taken at the beginning of the cycle at the FTW inlet. After 6 days, water was sampled in cells 1-4, and after the next 6 days in cell 5, too. The water sample was 1 litre of composite sample taken from 5 places in each cell (each corner and centre). Water samples were brought to the laboratory in refrigeration devices and stored until the moment of analyses according to the prescribed protocol.

Sanitary and microbiological analyses included determination of the number of total coliform bacteria in $100 \mathrm{ml}$ (TCB), the number of coliform bacteria of faecal origin in $100 \mathrm{ml}(\mathrm{CBoFO})$, the number of intestinal enterococci in $100 \mathrm{ml}$ (IE), the number of aerobic heterotrophs in $1 \mathrm{ml}(\mathrm{H})$ and facultative oligotrophs in $1 \mathrm{ml}$ (FO), as well as their ratio. The number of total coliform bacteria and the number of coliform bacteria of faecal origin was determined in accordance with the standard method SRPS EN ISO 9308-2:2015 (Water quality - Enumeration of Escherichia coli and coliform bacteria - Part 2: Most probable number method.), while the number of intestinal enterococci was determined based on the instructions for use of rapid tests made by Idexx (IDEXX Water Enterolert-E and IDEXX Water Enterolert-DW, AFNOR IDX 33/04-02/15). The number of aerobic heterotrophs, the number of facultative oligotrophs and their ratio was determined based on Petrović et al. (1998).

\section{RESULTS}

The results of microbiological analysis of polluted and purified water from sanitary and ecological aspect (Tables 1 and 2) have shown that biological system was extremely effective in removing various categories of microorganisms, which impair water quality.

The number of coliform bacteria of faecal origin (CBoFO) in inflow amounted to $1,209,800.0$ in $100 \mathrm{ml}$ (Table 1.). The number of these pathogenic microorganisms was reduced after only six days of treatment in cells with plants (Table 2). The lowest value of $\mathrm{CBoFO}$ has been recorded in cell 2 where the species $C$. indica reduced the number of bacteria to 166.4 in $100 \mathrm{ml}$ (Table 1) with $100 \%$ removal efficiency (Table 2). Compared to other cells, the reduction of number of $\mathrm{CBoFO}$ was the least in cell 4 with decorative macrophytes, but removal efficiency was also $100 \%$ (Table 2) in relation to the initial content of these pathogenic microorganisms in the inflow. At the end of treatment, CBoFOs were below the detection limit (Table 1) so that the efficiency of CBoFOs removal was $100 \%$ (Table 2).

The number of total coliform bacteria (TCB) was equal to the number of CBoFO in the inflow (Table 1). The reduction of TCB was the highest in cell 1 with the species $P$. australis where 1,299.7 coliform bacteria was recorded in 100 $\mathrm{ml}$ (Table 1), and the lowest in cell 4 with decorative macrophytes with the 
removal efficiency of $97 \%$ (Table 2). At the end of the treatment, after the discharge of water from cell 5, the removal efficiency of TCB was 100\% (Table 2).

The number of intestinal enterococci (IE) in the inflow amounted to $2,419.8$ in $100 \mathrm{ml}$ (Table 1). The removal of IE has been significant already after first 6 days of treatment in cells with plants, so that the number of IE ranged within the limits from 71.7 to 196.8 in $100 \mathrm{ml}$ (Table 1). The lowest number of IE was recorded in cell 2 with the species $C$. indica with the removal efficiency of $97 \%$ (Table 2). In cell 1 with the species $P$. australis the removal of IE was the least compared to other cells and it amounted to $92 \%$ (Table 2). Until the end of the treatment the number of IE was reduced to the value of 46.4. Therefore, the removal efficiency for IE in the modified FTW was $98 \%$ (Table 2).

Table 1. The number of coliform bacteria of faecal origin, total coliform bacteria, and intestinal enterococci in polluted and purified water

\begin{tabular}{|l|r|r|r|r|r|r|}
\hline \multirow{2}{*}{ Parameter } & \multicolumn{7}{|c|}{ Sampling location } \\
\cline { 2 - 7 } & \multicolumn{1}{|c|}{ Inflow } & \multicolumn{1}{c|}{ Cell 1 } & \multicolumn{1}{c|}{ Cell 2 } & \multicolumn{1}{c|}{ Cell 3 } & \multicolumn{1}{c|}{ Cell 4 } & \multicolumn{1}{c|}{ Cell 5 } \\
\hline CBoFO & $1,209,800.0$ & 224.7 & 166.4 & 435.2 & $3,150.0$ & $<1.0$ \\
\hline $\mathrm{TCB}$ & $1,209,800.0$ & $1,299.7$ & $1,413.6$ & $1,986.3$ & $34,850.0$ & 2.0 \\
\hline $\mathrm{IE}$ & $2,419.8$ & 196.8 & 71.7 & 157.6 & 166.4 & 46.4 \\
\hline
\end{tabular}

Each value represents the value of a composite sample taken from 5 spots in a cell. CBoFO - the number of coliform bacteria of faecal origin in $100 \mathrm{ml}$, TCB - the number of total coliform bacteria in $100 \mathrm{ml}$, IE - the number of intestinal enterococci in $100 \mathrm{ml}$. Cell 1 - Phragmites australis (Cav.) Trin. ex Steud., Cell 2 - Canna indica L., Cell 3 - P. australis and C. indica, Cell 4 - Iris pseudacorus L., Iris sibirica 'Perry's Blue', Alisma plantago - aquatica L., Lythrum salicaria L. and Menyanthes trifoliata L., Cell 5 - algae (Cladophora sp.).

Table 2. The efficiency of removal of pathogenic microorganisms from polluted water (\%)

\begin{tabular}{|l|r|r|r|r|r|}
\hline \multirow{2}{*}{ Parameter } & \multicolumn{6}{|c|}{ Sampling location } \\
\cline { 2 - 6 } & \multicolumn{1}{|c|}{ Cell 1 } & \multicolumn{1}{|c|}{ Cell 2 } & \multicolumn{1}{c|}{ Cell 3 } & \multicolumn{1}{c|}{ Cell 4 } & \multicolumn{1}{c|}{ Outflow of FTW } \\
\hline CBoFO & 100 & 100 & 100 & 100 & 100 \\
\hline TCB & 100 & 100 & 100 & 97 & 97 \\
\hline IE & 92 & 97 & 93 & 93 & 90 \\
\hline
\end{tabular}

CBoFO - coliform bacteria of faecal origin, TCB - total coliform bacteria, IE - intestinal enterococci. Cell 1 Phragmites australis (Cav.) Trin. ex Steud., Cell 2 - Canna indica L., Cell 3 - P. australis i C. indica, Cell 4 - Iris pseudacorus L., Iris sibirica 'Perry's Blue', Alisma plantago - aquatica L., Lythrum salicaria L. and Menyanthes trifoliata L., Outflow of FTW - outflow of cell 5.

The number of aerobic heterotrophs in the inflow amounted to 77,000.00 in $1 \mathrm{ml}$ (Table 3). The reduction of number of aerobic heterotrophs $(\mathrm{H})$ was also significant after only 6 days of the treatment in cells with plants and it ranged within the limits from 3,182.00 to $16,364.00$ in $1 \mathrm{ml}$ (Table 3). The lowest number of $\mathrm{H}$ was recorded in cell 1 with the species $P$. australis, and the highest in cell 2 with the species $C$. indica (Table 3 ). At the end of the treatment in the water of cell 5 the number of $\mathrm{H}$ amounted to 1,591.00 in $1 \mathrm{ml}$ (Table 3).

The number of facultative oligotrophs (FO) in the inflow amounted to $94,000.00$ in $1 \mathrm{ml}$ (Table 3). After 6 days of treatment in cell with plants the number of FO was reduced, and it ranged from $13,182.00$ to $35,909.00$ in $1 \mathrm{ml}$ (Table 3). The lowest number of FO was recorded in cell 3 in which species $P$. 
australis and $C$. indica were planted, and the highest was in the cell 4 with decorative macrophytes (Table 3). The number of FO in the water of cell 5 at the end of the treatment amounted to 23,318.00 in $1 \mathrm{ml}$ (Table 3).

The ratio of aerobic heterotrophs and facultative oligotrophs $(\mathrm{FO} / \mathrm{H})$ both in polluted and purified water was above 1. The value of this parameter in the inflowing water amounted to 1.22 while in cells it ranged from 1.28 to 14.66. The lowest value of $\mathrm{FO} / \mathrm{H}$ was recorded in cell 2 with the species $C$. indica, and the highest in cell 5 with algae.

Table 3. The number of aerobic heterotrophs and facultative oligotrophs and their ratio in polluted and purified water

\begin{tabular}{|l|r|r|r|r|r|r|}
\hline \multirow{2}{*}{ Parameter } & \multicolumn{7}{|c|}{ Sampling location } \\
\cline { 2 - 8 } & \multicolumn{1}{|c|}{ Cell } & \multicolumn{1}{c|}{ Cell 1 } & \multicolumn{1}{c|}{ Cell 2 } & \multicolumn{1}{c|}{ Cell 3 } & \multicolumn{1}{c|}{ Cell 4 } & \multicolumn{1}{c|}{ Cell 5 } \\
\hline H & $77,000.00$ & $3,182.00$ & $16,364.00$ & $5,909.00$ & $11,818.00$ & $1,591.00$ \\
\hline FO & $94,000.00$ & $26,667.00$ & $20,952.00$ & $13,182.00$ & $35,909.00$ & $23,318.00$ \\
\hline FO/H & 1.22 & 8.38 & 1.28 & 2.23 & 3.04 & 14.66 \\
\hline
\end{tabular}

Each value represents a value of a composite sample taken from 5 spots in a cell. $\mathrm{H}-$ the number of aerobic heterotrophs in $1 \mathrm{ml}, \mathrm{FO}$ - the number of facultative oligotrophs in $1 \mathrm{ml}, \mathrm{FO} / \mathrm{H}$ - the ratio of aerobic heterotrophs and facultative oligotrophs, Cell 1 - Phragmites australis (Cav.) Trin. ex Steud., Cell 2 - Canna indica L., Cell 3 P. australis and C. indica, Cell 4 - Iris pseudacorus L., Iris sibirica 'Perry's Blue', Alisma plantago - aquatica L., Lythrum salicaria L. and Menyanthes trifoliata L., Cell 5 - algae (Cladophora sp.).

\section{DISCUSSION}

Polluted and wastewater contain various pathogens, such as parasites, viruses, and bacteria, which can cause serious diseases in humans and animals (hepatitis A, typhus, cholera, dysentery, etc.). Coliform bacteria (TCB and CBoFO) and intestinal enterococci (IE) are most used as indicators of water contamination by pathogens (National Risk Management Research Laboratory, 2000). The mechanism of pathogen removal itself is not clear enough, but it is assumed that they are removed from water based on physical and biological processes (Stottmeister et al., 2003). In the inflow of polluted water, pathogenic microorganisms are bound to solid particles in the water or are present in it in the form of suspensions (National Risk Management Research Laboratory, 2000). Those that are bound to solid particles are removed from the water through the processes of filtration, sedimentation, adsorption, and aggregation (Ottová et al., 1997). Some of the pathogens, which are free in water, compete with other microorganisms and usually do not survive (National Risk Management Research Laboratory, 2000), because only the microorganisms that can make symbiotic relationships with the root system can survive in the rhizosphere. Within cell 5 with algae, where a larger surface area of free water appeared, pathogen elimination occurred also due to UV radiation (Ottová et al., 1997). The species $P$. australis and $A$. plantago - aquatica are mentioned in the literature as very efficient plants, which, due to root exudates, provide stimulating effects for the growth of colonies of beneficial microorganisms, and inhibition of further pathogen development in polluted water (Stottmeister et al., 2003). Watson et al. (1989) state that various engineered biological systems for purification of polluted water have an 
exceptional ability to reduce the number of pathogenic microorganisms in water, whereby their efficiency ranges around $90 \%$ for coliform bacteria and about $80 \%$ for intestinal enterococci.

The results of assessing the efficiency of the modified FTW in this study confirm the general efficiency of biological systems for water treatment, noting that higher efficiency was achieved in modified FTW than the data stated in the literature. Within the cells with floating islands, $100 \%$ efficiency in removal of $\mathrm{CBoFO}$ was achieved, and pathogen reduction was continued within the cell with algae. In all cells, the efficiency of TCB removal was $100 \%$, except in the cell 4 with decorative aquatic macrophytes, in which the efficiency was $97 \%$. The number of IE was reduced in the range from 92 to $97 \%$ in cells with plants, and up to $98 \%$ in the cell with algae. The good efficiency of the modified FTW in the removal of various pathogens can be indicated by comparing the number of $\mathrm{CBoFO}$, TCB and IE, as parameters for assessing the ecological status of water (The Official Gazette of the Republic of Serbia, 2011), in inflow and outflow of modified FTW. Based on the number of $\mathrm{CBoFO}$ and the number of TCB, the inflow belonged to class V, and based on the number IE to class III (The Official Gazette of the Republic of Serbia, 2012). After the passage of water through the biological system and a significant reduction in the number of pathogenic microorganisms, the outflow of FTW was classified in class I (water with excellent ecological status) (The Official Gazette of the Republic of Serbia, 2012).

Aerobic heterotrophs $(\mathrm{H})$ are indicators of water quality from the aspect of its organic pollution. The high value of these microorganisms indicates waters, which are highly loaded with organic substances that are subject to microbiological decomposition. On the other hand, facultative oligotrophs (FO) are indicators of water less loaded with organic matter. Based on the results of this study the inflow of the FTW belonged to class III, i.e., water with moderate ecological status in terms of number of $\mathrm{H}$ (The Official Gazette of the Republic of Serbia, 2012). After the passage through the biological system, based on the reduced number of $\mathrm{H}$, the water had the characteristics of water with good ecological status (The Official Gazette of the Republic of Serbia, 2012). In this way, a shift for one water quality class has been achieved. Based on the ratio of the number of facultative oligotrophs and aerobic heterotrophs $(\mathrm{FO} / \mathrm{H})$, the possibility of water self-purification is determined. As can be seen in the tables presented, the value of $\mathrm{FO} / \mathrm{H}$ was above 1 during the entire water treatment, which indicates a satisfactory possibility of selfpurification. In addition, water in which the value of $\mathrm{FO} / \mathrm{H}$ is above 10 , which was the case with the water of outflow of the biological system, belong to the I class of waters (The Official Gazette of the Republic of Serbia, 2011).

\section{CONCLUSION}

Various types of biological systems, which enable the removal of various types of pollutants from water, are gaining more and more importance not only in scientific research but also in practice. This green technology enables achieving the ecological optimum with the preservation and sustainability of natural resources. Since it does not require high investments, it enables quantitative and qualitative economic, social, and other effects in a long term, so it is also economically 
acceptable. On the other hand, secondary and tertiary processes in conventional water treatment plants require a heavy use of technology, energy and various chemicals that additionally pollute the environment, while they can fail in complete removal of pathogens. In this paper, it is shown that the modified FTW has a high efficiency in removing pathogens from the water of a polluted urban river. The results clearly show that the overall achieved efficiency of the biological system in the removal of coliform bacteria of faecal origin and total coliform bacteria is $100 \%$, and for intestinal enterococci $98 \%$. Also, floating islands and algae enabled a high reduction in the number of aerobic heterotrophs and facultative oligotrophs. In addition, the ratio of these microorganisms had a value above 1 during the entire water treatment, which indicated that the natural processes of self-purification of polluted water ran smoothly in the FTW. Due to the reduction of pathogenic microorganisms, water that belonged to class V, i.e., III, after the discharge from the biological system, had the characteristics of water with excellent ecological status (class I). Surface waters belonging to this class, based on limit values of pathogenic microorganisms, provide conditions for the functioning of ecosystems, life and protection of fish, and can be used for drinking water supply with prior treatment by filtration and disinfection, bathing and recreation, irrigation and industrial use.

Acknowledgements The paper is the result of research within the projects: "Revitalization of Topčiderska River using biological systems for the treatment of polluted water" (Contract No. V-01 401.1-83), funded by the Secretariat for Environmental Protection of the City of Belgrade.

\section{REFERENCES}

Benvenuti, T., Hamerski, F., Giacobbo, A., Bernardes, A.M., Zoppas-Ferreira, J., Rodrigues, M.A. (2018): Constructed floating wetland for the treatment of domestic sewage: a real-scale study. Journal of environmental chemical engineering. 6(5), 57065711 .

Blaylock, M., Huang, J. (2000): Phytoextraction of metals, in: Raskin, I., Ensley, D.B. (Eds.), Phytoremediation of toxic metals: using plants to clean up the environment. John Wiley and Sons, Inc, New York, 53-69.

Brašanac-Bosanac, L., Čule, N., Lučić, A., Veselinović, M., Mitrović, S. (2020): Guidelines for the introduction of biological systems for revitalization of polluted water and wastewater treatment in strategic documents in Serbia. Sustainable Forestry. (81-82), 149157.

Chance, L.M.G., Van Brunt, S.C., Majsztrik, J.C., White, S.A. (2019): Short-and long-term dynamics of nutrient removal in floating treatment wetlands. Water research. 159, 153-163.

Chapman, D., Kimstach, V. (1996): Selection of water quality variables, in: Chapman, D. (Ed.) Water Quality Assessments - A guide to the use of biota, sediments and water in environmental monitoring. E \& FN Spon on behalf of UNESCO/WHO/UNEP, 59-126.

Chen, C., Zhao, T., Liu, R., Luo, L. (2017): Performance of five plant species in removal of nitrogen and phosphorus from an experimental phytoremediation system in the Ningxia 
irrigation area. Environmental monitoring and assessment. 189(10), 1-13. https://doi.org/https://doi.org/10.1007/s10661-017-6213-y.

Cule, N., Lucic, A., Nesic, M., Veselinovic, M., Mitrovic, S., Sredojevic, Z., BrasanacBosanac, L. (2021): Accumulation of chromium and nickel by Canna indica and decorative macrophytes grown in floating treatment wetland. Fresenius Environmental Bulletin. 30(6 B), 7881-7890.

Cule, N., Vilotic, D., Nesic, M., Veselinovic, M., Drazic, D., Mitovic, S. (2016): Phytoremediation potential of Canna indica L. in water contaminated with lead. Fresenesius Environmental Bulletin. 25(11), 3728-3733.

Čule, N., Lučić, A., Dražić, D., Popović, V., Veselinović, M., Brašanac-Bosanac, L., Mitrović, S. (2017): Construction of floating treatment wetlands for remediation of polluted waters. Sustainable Forestry (75-76), 1-12.

Davis, L. (1995): A handbook of constructed wetlands: A guide to creating wetlands for: agricultural wastewater, domestic wastewater, coal mine drainage, stormwater. In the MidAtlantic Region. Volume 1: General considerations. USDA-Natural Resources Conservation Service.

Dushenkov, V., Kumar, P.B.A.N., Motto, H., Raskin, I. (1995): Rhizofiltration: The Use of Plants to Remove Heavy Metals from Aqueous Streams. Environmental Science \& Technology. 29(5), 1239-1245.

Ghermandi, A., Bixio, D., Traverso, P., Cersosimo, I., Thoeye, C. (2007): The removal of pathogens in surface-flow constructed wetlands and its implications for water reuse. Water Sci Technol. 56(3), 207-216.

Jasper, J.T., Nguyen, M.T., Jones, Z.L., Ismail, N.S., Sedlak, D.L., Sharp, J.O., Luthy, R.G., Horne, A.J., Nelson, K.L. (2013): Unit Process Wetlands for Removal of Trace Organic Contaminants and Pathogens from Municipal Wastewater Effluents. Environ Eng Sci. 30(8), 421-436.

Kadlec, R.H., Wallace, S. (2008): Treatment wetlands, 2nd ed. Taylor \& Francis Group, CRC press, Boca Raton.

Kumar, P.B.A.N., Dushenkov, V., Motto, H., Raskin, I. (1995): Phytoextraction: The Use of Plants To Remove Heavy Metals from Soils. Environmental Science \& Technology. 29(5), 1232-1238.

National Risk Management Research Laboratory, N. (2000): Manual Constructed Wetlands Treatment of Municipal Wastewaters. Cincinnati, OH., 1-166.

Ottová, V., Balcarová, J., Vymazal, J., (1997): Microbial characteristics of constructed wetlands. Water Science and Technology. 35(5), 117-123.

Petrović, O., Gajin, S., Matavulj, M., Radović, D., Svirčev, Z. (1998): Mikrobiološko ispitivanje kvaliteta površinskih voda. Institut za biologiju, Prirodno-matematički fakultet, Novi Sad. [Petrović, O., Gajin, S., Matavulj, M., Radović, D., Svirčev, Z. (1998): Miicrobiological testing of quality of surface waters. The Institute of Biology, Faculty of Sciences, Novi Sad] 
Prasad, M.N.V., de Oliveira Freitas, H.M. (2003): Metal hyperaccumulation in plants: biodiversity prospecting for phytoremediation technology. Electronic journal of biotechnology. 6(3), 285-321.

Službeni glasnik RS (2011): Pravilnik o parametrima ekološkog i hemijskog statusa površinskih voda i parametrima hemijskog i kvantitativnog statusa podzemnih voda. Službeni glasnik RS 74/2011. [The Official Gazette of the Republic of Serbia (2011): The rulebook on parameters of ecological and chemical status of surface waters and parameters of chemical and quantitative status of groundwater. The Official Gazette of the Republic of Serbia 74/2011.]

Službeni glasnik RS (2012): Uredba o graničnim vrednostima zagađujućih materija u površinskim i podzemnim vodama i sedimentu i rokovima za njihovo dostizanje, Službeni glasnik RS 50/2012. [The Official Gazette of the Republic of Serbia (2012): The regulation on limit values of pollutants in surface water, groundwater and sediment and deadlines for their achievement, The Official Gazette of the Republic of Serbia, RS 50/2012.]

Salt, D.E., Blaylock, M., Kumar, N.P.B.A., Dushenkov, V., Ensley, B.D., Chet, I., Raskin, I. (1995): Phytoremediation: A Novel Strategy for the Removal of Toxic Metals from the Environment Using Plants. Bio/Technology. 13(5), 468-474.

Sharma, R., Vymazal, J., Malaviya, P. (2021): Application of floating treatment wetlands for stormwater runoff: A critical review of the recent developments with emphasis on heavy metals and nutrient removal. Science of The Total Environment. 777, 146044.

Stottmeister, U., Wießner, A., Kuschk, P., Kappelmeyer, U., Kästner, M., Bederski, O., Müller, R., Moormann, H. (2003): Effects of plants and microorganisms in constructed wetlands for wastewater treatment. Biotechnology advances. 22(1-2), 93-117.

Vymazal, J. (2007): Removal of nutrients in various types of constructed wetlands. Science of the total environment. 380(1-3), 48-65.

Vymazal, J. (2011): Constructed Wetlands for Wastewater Treatment: Five Decades of Experience. Environmental Science \& Technology. 45(1), 61-69.

Watson, J.T., Reed, S.C., Kadlec, R.H., Knight, R.L., Whitehouse, A.E., (1989): Performance expectations and loading rates for constructed wetlands, in: Hammer, D.A. (Ed.) Constructed wetlands for wastewater treatment Municipal, Industrial, and Agricultural. CRC Press, Taylor \& Francis, Boca Raton, pp. 319-351.

Yeh, N., Yeh, P., Chang, Y.-H. (2015): Artificial floating islands for environmental improvement. Renewable and Sustainable Energy Reviews. 47, 616-622. https://doi.org/https://doi.org/10.1016/j.rser.2015.03.090. 


\title{
THE REMOVAL OF PATHOGENIC MICROORGANISMS IN A BIOLOGICAL SYSTEM WITH FLOATING ISLANDS
}

\author{
Nevena $\check{C} U L E$, Aleksandar LUČIĆ, Marija NEŠIĆ, Ljiljana BRAŠANAC-BOSANAC, \\ Suzana MITROVIĆ, Milorad VESELINOVIĆ, Tatjana ĆIRKOVIĆ-MITROVIĆ
}

\begin{abstract}
Summary
The most common risk to human health associated with water comes from the presence of microorganisms that cause various diseases. Sewage, agricultural runoff and rainwater as well as household wastewater which are often mixed with each other and discharged into rivers without prior treatment pose a big problem. Such waters carry with them various pathogens and pose a great risk. Various biological systems can remove various pathogenic microorganisms from polluted and wastewater. Removal occurs by imitation of natural processes, without the use of chemicals and additional energy, and due to the symbiotic relationship between the basic components of biological systems such as plants, algae, small invertebrates, zooplankton, microorganisms, substrate, and water. The Topčiderka river has been used for years as a collector of wastewater, rainwater, agricultural, urban and industrial wastewater. Therefore, throughout the year its water is within the limits of class $\mathrm{V}$ of waters based on most chemical, physical chemical and microbiological parameters for water quality assessment. To assess the possibility of using biological systems for the treatment of a polluted river, a modified floating treatment wetland (FTW) was constructed on its bank. This paper presents the achieved efficiency of an environmentally friendly and cost-effective solution for the removal of pathogenic microorganisms from water. The biological system consisted of a collection tank, four cells with floating islands and one cell with algae which enabled additional polishing. In each of the four cells there were 3 floating islands. The species Phragmites australis (Cav.) Trin. ex Steud, Canna indica L., Iris pseudacorus L., Iris sibirica 'Perry's Blue', Alisma plantago aquatica L., Lythrum salicaria L. and Menyanthes trifoliata L. were used for forming of island vegetation. The algae were introduced into cell 5 directly from the river. The FTW star-up period lasted a month and a half, after which the monitoring of its efficiency in the removal of pathogenic microorganisms began. The results of this research show that total realised efficiency of the modified FTW in the removal of coliform bacteria of faecal origin and total coliform bacteria is $100 \%$, and $98 \%$ for intestinal enterococci. In addition, the floating islands and algae enabled a high reduction in the number of aerobic heterotrophs and facultative oligotrophs. Also, the ratio of these microorganisms had a value above 1 during the entire water treatment, which indicated that the natural processes of selfpurification of polluted water ran smoothly in the system. Due to the reduction of pathogenic microorganisms, water that belonged to class V, i.e., class III, after the discharge from the biological system, had the characteristics of water with excellent ecological status (class I).
\end{abstract}




\title{
UKLANJANJE PATOGENIH MIKROORGANIZAMA U BIOLOŠKOM SISTEMU SA PLUTAJUĆIM OSTRVIMA
}

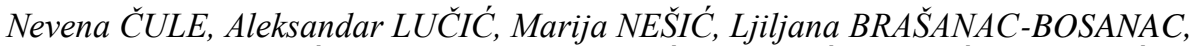 \\ Suzana MITROVIĆ, Milorad VESELINOVIĆ, Tatjana ĆIRKOVIĆ-MITROVIĆ
}

\section{Rezime}

Najčešći rizik po ljudsko zdravlje povezan sa vodom, potiče od prisustva mikroorganizama, koji izazivaju različite bolesti. Veliki problem predstavljaju kanalizacione, poljoprivredne i kišne otpadne vode, kako i otpadne vode iz domaćinstva, koje se često međusobno mešaju i bez prethodnog tretmana ispuštaju u reke. Ovakve vode sa sobom nose različite patogene i predstavljaju veliki rizik. Različiti biološki sistemi imaju mogućnost da uklanjaju različite patogene mikroorganizme iz zagađenih i otpadnih voda. Uklanjanje se dešava imitacijom prirodnih procesa, bez upotrebe hemikalija i dodatne energije, a zahvaljujući simbiotičkoj vezi između osnovnih komponenti bioloških sistema kao što su biljke, alge, mali beskičmenjaci, zooplankton, mikroorganizmi, supstrat i voda. Topčiderska reka se već godinama koristi kao kolektor otpadnih, kišnih, poljoprivrednih, gradskih i industrijskih voda. Zbog toga se tokom cele godine nalazi u granicama V klase voda na osnovu većine hemijskih, fizičko-hemijskih i mikrobioloških parametara za ocenu kvaliteta voda. Kako bi se ispitala mogućnost korišćenja bioloških sistema za tretman zagađene reke, na njenoj obali je konstruisan modifikovani sistem sa plutajućim ostrvima. Ovaj rad prikazuje postignutu efikasnost ekološki pogodnog i ekonomski isplativog rešenja za uklanjanje patogenih mikroorganizama iz vode. Biološki sistem se sastojao od sabirnog tanka, četiri bazena sa plutajućim ostrvima i jednog bazena sa algama, koji je omogućavao dodatno poliranje. U svakom od četiri bazena su se nalazila po 3 plutajuća ostrva. Za formiranje vegetacije ostrva korišćene su vrste Phragmites australis (Cav.) Trin. ex Steud, Canna indica L., Iris pseudacorus L., Iris sibirica 'Perry's Blue', Alisma plantago aquatica L., Lythrum salicaria L. i Menyanthes trifoliata L. Alge su u bazen 5 unesene direktno iz reke. Period uhodavanja biološkog sistema je trajao mesec i po dana, nakon čega je započet monitoring njegove efikasnosti u uklanjanju patogenih mikroorganizama. Rezultati istraživanja pokazuju da je ukupna ostvarena efikasnost biološkog sistema u uklanjanju koliformnih bakterija fekalnog porekla i ukupnih koliformnih bakterija $100 \%$, a crevnih enterokoka 98\%. Takođe, plutajuća ostrva i alge su omogućili visoko smanjenje brojnosti aerobnih heterotrofa i fakultativnih oligotrofa. Pored toga, odnos ovih mikroorganizama je imao vrednost iznad 1 tokom celog perioda prečišćavanja, što je ukazalo da su se u sistemu neometano odvijajali prirodni procesi samoprečišćavanja zagađene vode. Zahvaljujući redukciji patogenih mikroorganizama voda koja je pripadala V odnosno III klasi je po izlasku iz biološkog sistema imala karakteristike vode sa odličnim ekološkim statusom (I klasa). 